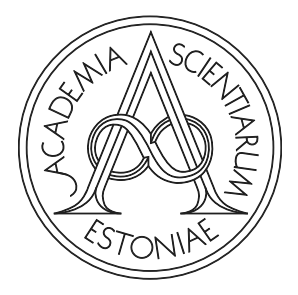

Proceedings of the Estonian Academy of Sciences, $2021,70,4,399-406$

https://doi.org/10.3176/proc.2021.4.05

Available online at www.eap.ee/proceedings

MANUFACTURING

ENGINEERING

\title{
Key performance indicators: contemporary challenges to industrial small and medium enterprises
}

\begin{abstract}
Rūta Banelienè
VILNIUS TECH (Vilnius Gediminas Technical University), J. Basanavičiaus g. 28, LT-03224, Vilnius, Lithuania; ruta.baneliene@vilniustech.lt

Received 2 June 2021, accepted 13 June 2021, available online 1 November 2021

(C) 2021 Author. This is an Open Access article distributed under the terms and conditions of the Creative Commons AttributionNonCommercial 4.0 International License (http://creativecommons.org/licenses/by-nc/4.0/).

Abstract. The paper investigates key challenges to the successful management of industrial small and medium enterprises (SMEs) under conditions of globalization and provides a model for successful evaluation and monitoring of SME activities. The proposed model is universal and could be applied by industrial SMEs with modest effort for developing databases such as product/material, equipment and production, as well as for measuring and monitoring the suggested key performance indicators (KPIs) in nine value chains: 1) inbound logistics; 2) operations; 3) outbound logistics; 4) marketing \& sales; 5) service; 6) human resources management; 7) technology development; 8) procurement; 9) sustainability. The first three value chains serve as a cornerstone of all KPIs for the 'house' of an industrial SME, while marketing \& sales, and service value chains are intended to measure a company's success via sales. Procurement KPIs should focus on measuring and monitoring the stock level as continuous flow, which would secure smoothness in all the operations of the company. However, special attention should be paid to human resources management, innovations and sustainability by setting and monitoring KPIs within the whole timeframe - the present, past and future.
\end{abstract}

Key words: key performance indicators, SME, industry, monitoring, evaluation.

\section{INTRODUCTION}

The development of small and medium enterprises (SMEs) into successful companies in the long run period is not an easy task, especially under globalization conditions. Competition among companies worldwide has a huge impact on enhancing companies' effort in setting and managing performance indicators during the entire PlanDo-Check-Act (PDCA) cycle. In this field, one of the cornerstone decisions is the identification (and setting) of activity measuring indicators that could help the management staff to achieve strategic, tactical and operational goals based on reliable information flows. Large companies have usually implemented a monitoring system of performance indicators via the information system (IS). However, for SMEs this possibility is still under challenging operations due to the lack of knowledge and funding for acquiring and applying such tools in the companies' every-day management.
The novelty of this paper is the focus on key performance indicators (KPIs) regarding manufacturing SMEs. Though plenty of research exists in this area, the scope of activities which are critically important for successful company development suggested by theoretical approaches and empirical evidence is still misunderstood.

Section 2 of this paper covers part of the theoretical approaches along with an overview of explicit areas for setting key performance indicators. Section 3 presents, according to empirical evidence, an overview of KPIs proposed by other authors in the field of managing and monitoring a company's activities by the value chain. In addition, it is also clarified what kind of performance indicators should be maintained as KPIs. Section 4 suggests a KPIs model for industrial SMEs based on the management of past, present and future operations. Section 5 summarizes the research and provides a definite conclusion on which activities, factors and indicators 
are the most important for monitoring industrial SMEs, especially under conditions of globalization.

\section{THEORETICAL APPROACH}

The basis of setting KPIs for SMEs and for a particular enterprise should be a clear structure linked to prioritization metrics according to their importance for a particular industrial business area. For example, the prioritization criteria could be: 1) value with the meaning of the impact of changes in process on output value; 2 ) speed with the meaning of the impact of changes in process on output speed; 3) quality with the meaning of the impact of changes in process on quality; and 4) the cost of measurement with the meaning of the metrics calculation cost.

The basis for comprehensive KPIs could be quality, productivity, and maintenance with supporting elements such as production and maintenance time as well as production output quantity and quality (Kang et al. 2016). In addition, while setting KPIs for a particular SME, extensive taxonomy should be considered, for example 3Ps (products, people, processes): tracking the activities related to the product or service supply chain and capital; as concerns people and human capital tracking and recognizing people, and locating them where they would be needed; physical or infrastructure operations as well as manufactured and natural capital resources should be chosen effectively by using the information and tools available on the Internet (Ramin and Lew 2015).

Company performance indicators should be based on the company strategy that usually involves the strategy map, balanced scorecard (BSC), KPIs at the company level and their division by separate departments. The entire process is usually accomplished by the organizational structure of a particular SME and measurement of lower-level activities (Cao et al. 2015).

Strategic KPIs could be based on four perspectives such as financial output, internal operations, learning and growth, and customers - with a clear focus on the goal, measurement, indicator and action of a particular perspective. When setting indicators at the level of a more detailed balanced scorecard (BSC), it would be reasonable to structure them by supply chains: supplier, input, process, output and customer (Cao et al. 2015).

In the course of quality control (QC) and improvement activities, specialists should collect data, analyse it for valid information, disseminate it, generate knowledge about possible solutions, transfer that knowledge to other employees, and make it available for reuse. For example, the quality control story or the PDCA can structure such activities (Versiani et al. 2013).
According to ISO 22400:2014, manufacturing process should involve KPIs such as throughput rate, allocation ratio, and the three KPIs - quality ratio, availability and effectiveness - which are part of overall equipment effectiveness (OEE), and the OEE itself.

Hwang et al. (2017) suggest using a value stream for the calculation of manufacturing process KPIs, where materials are moving via different processes to the final product and could be tracked by radio-frequency identification (RFID) devices, sensors and the Internet of Things (IoT). In consideration of this detailed information, three kinds of databases should be developed by the company: 1) product/material; 2) equipment; and 3) production. Also, value stream data should be collected at every point by a number of very detailed indicators and measures.

Product portfolio renewal is concerned with adding new products to the product portfolio, enhancing and modifying the existing products and removing obsolete ones (Tolonen et al. 2015). Innovations and new products are essentially important for maintaining SMEs' competitive position on the market, especially under globalization conditions. Tolonen et al. (2015) suggest that a company's KPIs matrix focus on the product portfolio management process in interaction with the product process and supporting processes, on the one hand, and with customer processes such as sales, delivery and care processes, on the other hand.

Innovation KPIs could be set according to the innovation type - product, process, organizational activities, and marketing, while taking into account input, process and output stages (Banelienè 2019).

The establishment of global production sites in lowcost regions is a key force inducing a more recent trend in western manufacturing companies - the global distribution of product development (GPD). This represents a major transformation in industry as companies switch from managing engineering teams, which were previously collocated and cross-functional, to managing teams that are geographically dispersed and culturally diverse to develop products in a collaborative manner. If a company deals with global product development projects, it should set and consider multiple risks such as cultural differences, physical proximity, difficulties with communication, trust, difficulties with documentation, lack of common vision, protection of intellectual property rights, knowledge sharing coordination, and standardization of tools and processes (Taylor and Ahmed-Kristensen 2018).

Based on circular economy (CE) principles, EMF (2012) suggests a number of approaches to implement for revalorization, including: 1) design out waste; treat waste as a resource; 2) design for disassembly; standardization and modularization; 3) select feedstock materials based on circularity potential; 4) promote resilience through diversity; 5) obtain energy from renewable sources; and 
6) think in 'systems and cascades'. It seems counterintuitive to use a single metric for a concept like circularity which is clearly multi-faceted. Product circularity depends on the lens through which it is viewed: impact measure (energy, $\mathrm{CO}_{2}$, equity); lifecycle stage (manufacturing, using, 'end of life'); activity type (design, marketing, refurbishment) (Cayzer et al. 2017).

\section{EMPIRICAL EVIDENCE}

A value chain could be one of the approaches for structuring KPIs. Considering Porter's generic value chain (1998) with its five primary activities - inbound logistics, operations, outbound logistics, marketing \& sales, and service, as well as with four support activities - firm infrastructure, human resources management, technology development, and procurement, it could be a good initial base for the setting of KPIs. However, in this paper on the analysis of KPIs we modify the generic value chain by adding two additional chains - a financial chain and a sustainability chain - and exclude a firm infrastructure chain due to the lack of proposed KPIs in scientific literature.

Table 1 indicates ten possible areas of KPIs, five of which apply to the supply chain: inbound logistics, operations, outbound logistics, marketing \& sales, and services. Other KPIs relate to areas where know-how management could create competitive advantages for a company - human resources management (HRM), technology development, procurement, finance, and

Table 1. KPIs overview by the value chain structure

\begin{tabular}{|c|c|c|}
\hline Value chain & KPIs & Author \\
\hline \multirow[t]{3}{*}{ Inbound logistics } & quality of delivered goods, supplier delivery efficiency & $\begin{array}{l}\text { Werner et al. } 2020 \text {; } \\
\text { Karl et al. } 2018\end{array}$ \\
\hline & $\begin{array}{l}\text { order lead time, delivery lead time, on-time delivery of goods, } \\
\text { supplier rejection rate }\end{array}$ & Karl et al. 2018 \\
\hline & supplier satisfaction & Cao et al. 2015 \\
\hline \multirow[t]{5}{*}{ Operations } & $\begin{array}{l}\text { throughput rate, allocation ratio, quality ratio, availability, } \\
\text { effectiveness, overall equipment effectiveness (OEE) }\end{array}$ & ISO 22400:2014 \\
\hline & capacity utilization & $\begin{array}{l}\text { Werner et al. 2020; } \\
\text { Karl et al. } 2018\end{array}$ \\
\hline & labour productivity of all employees, number of major accidents & Cao et al. 2015 \\
\hline & $\begin{array}{l}\text { manufacturing data error, calibration of equipment expired, failure } \\
\text { to install safety equipment, assembly error, error preparing work } \\
\text { instruction, non-application of an engineering change }\end{array}$ & Souza et al. 2020 \\
\hline & list of late projects & Parmenter 2020 \\
\hline $\begin{array}{l}\text { Outbound } \\
\text { logistics }\end{array}$ & late deliveries to key customers & Parmenter 2020 \\
\hline \multirow[t]{2}{*}{$\begin{array}{l}\text { Marketing \& } \\
\text { sales }\end{array}$} & customer satisfaction & $\begin{array}{l}\text { Cao et al. 2015; } \\
\text { Taylor and } \\
\text { Ahmed-Kristensen } \\
\text { 2018; Karl et al. } \\
\text { 2018; Werner } \\
\text { et al. } 2020\end{array}$ \\
\hline & $\begin{array}{l}\text { number of franchised stores, market share, strategic business sales } \\
\% \text {, growth rate of export sales, brand reputation, investment in } \\
\text { charity and education }\end{array}$ & Cao et al. 2015 \\
\hline \multirow[t]{2}{*}{ Service } & damage return rate & Karl et al. 2018 \\
\hline & $\begin{array}{l}\text { complaints from key customers, which have not been resolved within } \\
2 \mathrm{~h} \text {, key customer enquiries that have not been responded over } 24 \mathrm{~h} \text {, } \\
\text { date of next visit to major customers by customer name }\end{array}$ & Parmenter 2020 \\
\hline \multirow{3}{*}{$\begin{array}{l}\text { Human resources } \\
\text { management } \\
(\mathrm{HRM})\end{array}$} & promotion rate of employees, employee satisfaction & Cao et al. 2015 \\
\hline & $\begin{array}{l}\text { staff in vital positions who have handed in their notices in the last } \\
\text { hour; key position job offers issued to candidates, which have been } \\
\text { outstanding for more than } 3 \text { days; number of vacant places at an } \\
\text { important in-house course; number of initiatives implemented after } \\
\text { the staff-satisfaction survey; number of abandonments in the next } 30 \text {, } \\
60 \text {, or } 90 \text { days }\end{array}$ & Parmenter 2020 \\
\hline & $\begin{array}{l}\text { employee development, satisfaction, health and safety, fair } \\
\text { compensation ratio and pay equity, fair trade and labour practices }\end{array}$ & $\begin{array}{l}\text { Shields and } \\
\text { Shelleman } 2020\end{array}$ \\
\hline
\end{tabular}


Table 1. Continued

\begin{tabular}{|c|c|c|}
\hline Value chain & KPIs & Author \\
\hline \multirow[t]{4}{*}{$\begin{array}{l}\text { Technology } \\
\text { development }\end{array}$} & $\begin{array}{l}\text { total benefits from innovation, rate of new products' output value, } \\
\text { timely review rate of orders, on-schedule completion rate of samples, } \\
\text { number of universalized products, completion rate of Standard } \\
\text { Operating Procedure (SOP) preparation, completion rate of process } \\
\text { preparation, eligibility rate of the spot check of outsourced finished } \\
\text { products, number of newly developed products, number of } \\
\text { completed projects on process innovation, number of technical } \\
\text { improvement projects on learning and growth }\end{array}$ & Cao et al. 2015 \\
\hline & $\begin{array}{l}\text { number of innovations planned for implementation in the next } 30 \text {, } \\
60 \text {, or } 90 \text { days }\end{array}$ & Parmenter 2020 \\
\hline & $\begin{array}{l}\text { parts with plug-in or reliability problems (bill of materials, } \\
\text { engineering change notice errors) }\end{array}$ & Souza et al. 2020 \\
\hline & $\begin{array}{l}\text { planned vs actual resources, cost of delay, project lead time, number } \\
\text { of product lifecycles, documentation errors, documentation approval } \\
\text { time, document approval delays, internal design expert feedback, } \\
\text { feedback on assembly }\end{array}$ & $\begin{array}{l}\text { Taylor and } \\
\text { Ahmed-Kristensen } \\
2018\end{array}$ \\
\hline \multirow[t]{2}{*}{ Procurement } & stock level & $\begin{array}{l}\text { Werner et al. 2020; } \\
\text { Karl et al. } 2018\end{array}$ \\
\hline & material problems, damaged parts from the supplier & Souza et al. 2020 \\
\hline \multirow[t]{2}{*}{ Finance } & $\begin{array}{l}\text { return on net assets, business income, rate of return on sales, total } \\
\text { assets turnover, asset-liability rate, rate of new products' output } \\
\text { value, investment in research and development (R\&D) }\end{array}$ & Cao et al. 2015 \\
\hline & $\begin{array}{l}\text { global product development (GPD) cost of product development, } \\
\text { GPD return on investment }\end{array}$ & $\begin{array}{l}\text { Taylor and } \\
\text { Ahmed-Kristensen } \\
2018\end{array}$ \\
\hline \multirow[t]{3}{*}{ Sustainability } & $\begin{array}{l}\text { community engagement and contributions, diversity policies and } \\
\text { practices, energy sources and usage, greenhouse gas emissions, } \\
\text { landfill diversion, local sourcing, sustainability-related performance } \\
\text { measures, product and packaging resource efficiency, recycled } \\
\text { inputs, reuse and recycling of waste, sharing and collaboration, } \\
\text { supplier audits, water usage }\end{array}$ & $\begin{array}{l}\text { Shields and } \\
\text { Shelleman } 2020\end{array}$ \\
\hline & $\begin{array}{l}\text { energy efficiency, or energy consumption related to energy use, } \\
\text { compared to the energy baseline; reduced cost of energy; meeting } \\
\text { of overall climate change goals; improved reliability; increased use } \\
\text { of renewables }\end{array}$ & ISO 50001:2018 \\
\hline & $\begin{array}{l}\text { comprehensive energy consumption per output value, qualified } \\
\text { rate of environmental protection indicators; } \\
\text { proportion of biological inputs and feedstock derived from sources } \\
\text { defined as restorative; total quantities of non-renewable biological } \\
\text { materials and/or materials from sources classified as at risk, scarce } \\
\text { or vulnerable; proportion and quality of total original biological } \\
\text { materials returned to the biosphere; total quantity of technical } \\
\text { material flows through the supply chain including critical materials; } \\
\text { ratio of products and services designed for circularity versus all } \\
\text { categories of products and services by value and by the mass of } \\
\text { materials; total technical products and materials recovered and } \\
\text { recirculated through all of the product lifecycle via open or closed } \\
\text { loops; quality and planned longevity of technical materials in } \\
\text { product lifecycle; sales value of products and materials designed as } \\
\text { 'circular' as the ratio of all sales of products and services; value of } \\
\text { initial biological material inputs cascaded to subsequent cycles; total } \\
\text { renewable energy as \% of total consumption across the supply chain }\end{array}$ & $\begin{array}{l}\text { Cao et al. 2015; } \\
\text { Howard et al. } \\
2019\end{array}$ \\
\hline
\end{tabular}

sustainability. Supply chain areas - inbound logistics, operations, and outbound logistics - are mostly focused on time, output and quality KPIs. The KPIs of the two other areas - marketing \& sales, and services - are based on sales and other indicators assuring overall customer satisfaction. Supplementary value chain areas such as the HRM, technology development, and sustainability rely on strategic goals and values of the company. The last twoprocurement and finance - are focused on cost, quality and output results in financial terms. 
According to Parmenter (2020), KPIs should be set as indicators measuring last week, yesterday and today, as well as next week's performance in the future timeframe. Return on the capital employed, net promoter score, revenue per employee, economic value added, customer satisfaction rate or index, employee satisfaction rate or index are incorrectly called KPIs. KPIs are those indicators that focus on the aspects of organizational performance, being the most critical for the current and future success of the organization (Parmenter 2020).

\section{MODEL FOR INDUSTRIAL SMEs}

As stated by Parmenter (2020), the KPIs model for industrial SMEs should be based on seven characteristics of KPIs: non-financial, timely, chief executive officer (CEO) focus, simple, team-based, significant impact, and limited dark side. His suggestion is to measure up to 100 indicators: around 10 KPIs (operational KPIs - reported 24/7, daily or weekly), 10 key result indicators (KRIs) (Board KPIs - reported at every board meeting) as well as 80 performance indicators (PIs) and result indicators (RIs) (reported daily, weekly, monthly) (Parmenter 2020).

In addition, for the development of the KPIs model, different roles of scorecards and dashboards should be taken into account: scorecards are strategic in focusing on progress toward strategic objectives, dashboards are operational in monitoring and measuring processes (Eckerson 2010; Cokins 2020). Therefore, the KPIs model for industrial SMEs would be based on scorecards' indicators.

Empirical evidence has clarified nine essential KPIs areas which could be referred to as value chains and would create for the company competitive advantages: 1) inbound logistics; 2) operations; 3) outbound logistics; 4) marketing \& sales; 5) service; 6) human resources management; 7) technology development; 8) procurement; and 9) sustainability.

Taking into consideration the role and time dimension of the strategic KPIs, the KPIs model for industrial SMEs suggests focusing on past, present and future indicators which could prevent failures, measure key success factors and create competitive advantages. The model is based on the idea of a house where value chains denote walls and timeframe refers to the groundwork of the house.

The inbound logistics value chain as the first chain in the construction stage of the house should be a reliable foundation for all the activities of the company and measured via the past, present and future (forecast or setting objectives) timeframe by delivered materials and components, etc. in terms of timeliness and good quality.

The second stage of the operations' value chain is essentially important for monitoring indicators such as:
1) quality ratio; 2) overall equipment effectiveness (OEE); 3) labour productivity of all employees - within the past and present timeframe.

The outbound logistics value chain should measure late deliveries to key customers in the present time. As shown in Fig. 1, this indicator would serve as the cornerstone for the further stages of the company house.

Marketing \& sales is the value chain that measures the success of the company's activities expressed via sales, as it should be the final strategic target of the operations of this chain. Therefore, in this area the following indicators should be monitored within the whole timeframe: 1) sales (in units) and sales revenue; 2) market share; and 3) growth rate of export sales. The last sub-indicator is very important for a SME's success in the long-term perspective due to diversification of risks by working in more than one market and for the benefit of company growth.

The service chain is one of the key SME activities which could create a competitive advantage via fast reaction to solving problems and could be measured by: 1) complaints from key customers, which have not been resolved within $2 \mathrm{~h}$; 2) key customer enquiries that have not been responded to for over $24 \mathrm{~h}$; and 3 ) damage return rate from the past-time perspective, which is a result of failures in the first, second and third value chains.

Human resources management is one of the key areas with the potential of creating significant competitive advantages and requires special top management attention. In this field, the indicator of the past timeframe could be the number of initiatives implemented after the staff-satisfaction survey. The KPIs of the present timeframe are as follows: 1) staff in vital positions who have handed in their notices in the last hour; 2) key position job offers issued to candidates, which have been outstanding for more than three days. The KPIs of the future timeframe include: 1) the number of vacant places at an important in-house course; 2) the number of abandonments to be actioned in the next 30,60 , or 90 days.

Technology development KPIs should be clearly focused on innovation in the past, present and future. For example, the number of newly developed products and the number of completed projects on process innovation could be set as the past KPIs. SMEs could also focus their attention on monitoring innovation in process by setting the number of technical improvement projects on learning and growth as an indicator. And being the whole time in innovation development process is crucially important for the technology development value chain. Therefore, as a strategic goal and a KPI within the future timeframe, the company could set and monitor, for example, the number of innovations planned for implementation in the next 30 , 60 , or 90 days.

The most important KPI for SMEs in the field of procurement should be the stock level, which as continuous 


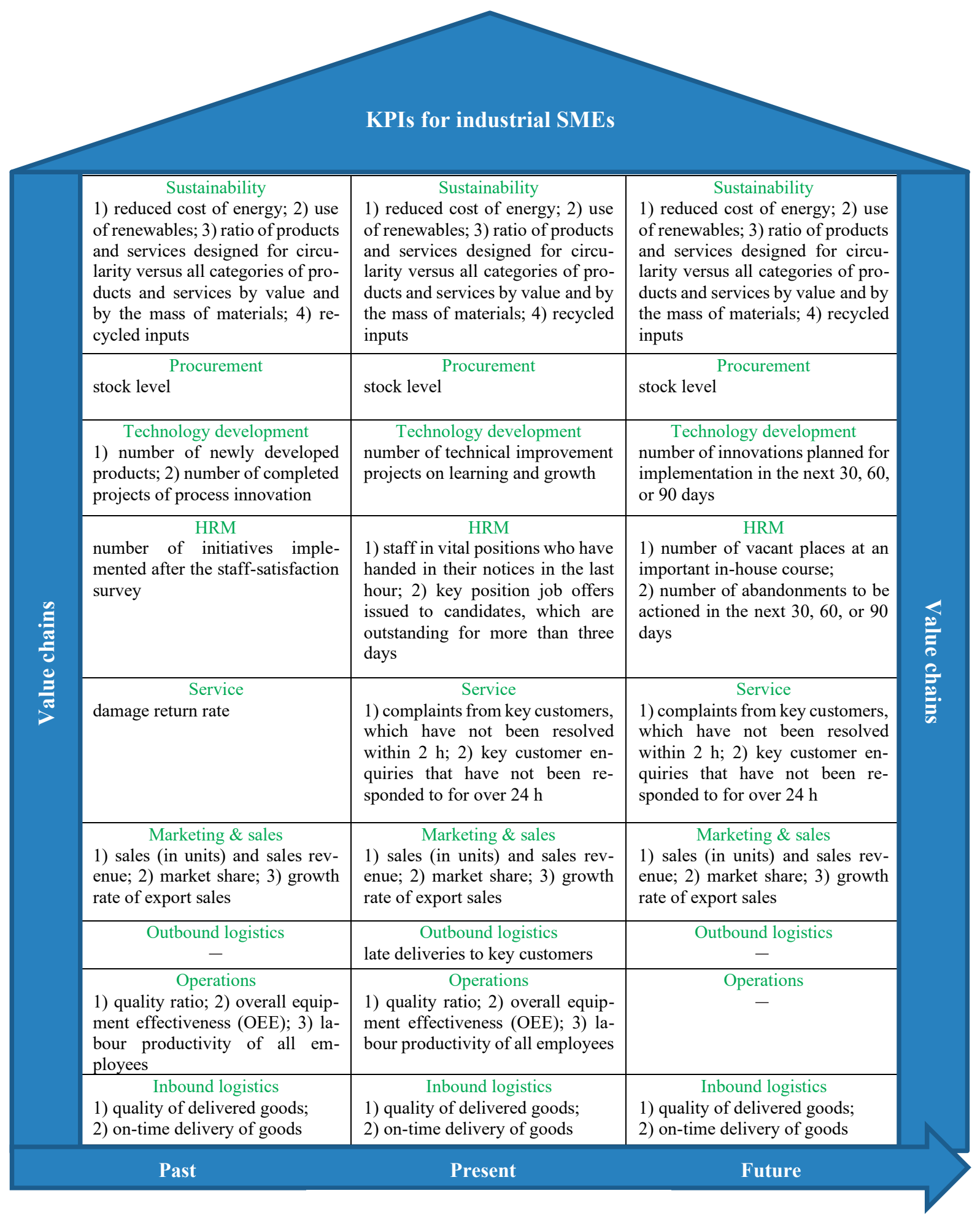

Fig. 1. KPIs model for industrial SMEs.

flow would secure smoothness in all the operations of the company.

Finally, the sustainability value chain, playing an important role in the values of developed countries, can be compared to the roof of the company house and should measure the following KPIs: 1) reduced cost of energy; 2) use of renewables; 3 ) ratio of products and services designed for circularity versus all categories of products, as well as services by value and by the mass of materials; and 4) recycled inputs (see Fig. 1). 


\section{CONCLUSIONS AND PROPOSALS}

The KPIs model for industrial SMEs should be based on seven characteristics - nonfinancial, timely, CEO focus, simple, team-based, significant impact, and limited dark side. It should cover no more than $20 \mathrm{KPIs}$ which monitor key strategic activities via the timeframe of the past, present and future (around $10 \mathrm{KPIs}$ and $10 \mathrm{KRIs}$ ).

The proposed model is universal and could be applied by industrial SMEs with modest effort for developing databases such as product/material, equipment and production (based on RFID, sensors and IoT information), as well as for measuring and monitoring the suggested KPIs by all the nine proposed value chains: 1) inbound logistics; 2) operations; 3) outbound logistics; 4) marketing \& sales; 5) service; 6) human resources management; 7) technology development; 8) procurement; and 9) sustainability. The first three value chains are like a cornerstone of the entire house of an industrial SME, while marketing \& sales, and service value chains are intended to measure the success of a company via sales. Procurement KPIs should focus on measuring and monitoring the stock level as continuous flow, which would secure smoothness in all the operations of the company. However, special attention should be paid to the HRM, innovations and sustainability by setting and monitoring KPIs within the whole timeframe - the present, past and future.

A major limitation of this research on the KPIs model for industrial SMEs is the validation in practice, which is planned as a future research step.

\section{ACKNOWLEDGEMENT}

The publication costs of this article were covered by the Estonian Academy of Sciences and Tallinn University of Technology.

\section{REFERENCES}

Banelienè, R. 2019. Innovation activities: contemporary approaches and indicators. Viešasis administravimas (Public administration), 56(1), 56-69.

Cao, Y., Zhao, K., Yang, J. and Xiong, W. 2015. Constructing the integrated strategic performance indicator system for manufacturing companies. Int. I. Prod. Res., 53(13), 41024116. https://doi.org/10.1080/00207543.2014.994715

Cayzer, S., Griffiths, P. and Beghetto, V. 2017. Design of indicators for measuring product performance in the circular economy. Int. J. Sustainable Eng., 10(4-5), 289-298. https://doi.org/10.1080/19397038.2017.1333543

Cokins, G. 2020. The strategy map and its balanced scorecard. EDPACS, 61(3), 1-16. https://doi.org/10.1080/07366981.2020. 1750799

Eckerson, W. 2010. Performance Dashboards: Measuring, Monitoring, and Managing your Business, 2nd ed. John Wiley \& Sons, Hoboken, NJ.
EMF (Ellen MacArthur Foundation). 2012. Towards the Circular Economy: Economic and Business Rationale for an Accelerated Transition. Report 1.

Howard, M., Hopkinson, P. and Miemczyk, J. 2019. The regenerative supply chain: a framework for developing circular economy indicators. Int. J. Prod. Res., 57(23), 73007318. https://doi.org/10.1080/00207543.2018.1524166

Hwang, G., Lee, J., Park, J. and Chang, T.-W. 2017. Developing performance measurement system for Internet of Things and smart factory environment. Int. J. Prod. Res., 55(9), 25902602. https://doi.org/10.1080/00207543.2016.1245883

ISO 22400:2014 (Parts 1 and 2). Automation Systems and Integration - Key Performance Indicators (KPIs) for Manufacturing Operations Management, 1st ed.

ISO 50001:2018. Energy Management Systems - Requirements with Guidance for Use.

Kang, N., Zhao, C., Li, J. and Horst, J. A. 2016. A hierarchical structure of key performance indicators for operation management and continuous improvement in production systems. Int. J. Prod. Res., 54(21), 6333-6350. https://doi.org/10.1080/00207543.2015.1136082

Karl, A. A., Micheluzzi, J., Leite, L. R. and Pereira, C. R. 2018. Supply chain resilience and key performance indicators: a systematic literature review. Production, 28, e20180020. https://doi.org/10.1590/0103-6513.20180020

Parmenter, D. 2020. Key Performance Indicators: Developing, Implementing and Using Winning KPIs, 4th ed. John Wiley \& Sons, Hoboken, NJ. https://lccn.loc.gov/2019024534

Porter, M. E. 1998. The Competitive Advantage: Creating and Sustaining Superior Performance. Free Press, New York, NY.

Ramin, K. and Lew, S. 2015. A model for integrated capital disclosure and performance reporting: separating objects from value. J. Sustain. Finance Invest., 5(1-2), 27-47. https://doi.org/10.1080/20430795.2015.1042829

Shields, J. F. and Shelleman, J. M. 2020. SME sustainability dashboards: an aid to manage and report performance. J. Small Bus. Strategy, 30(2), 106-114.

Souza, R., Sousa, S. and Nunes, E. 2020. Developing organisational learning through QC story. Total Qual. Manag. Bus. Excell., 31(13-14), 1565-1587. https://doi.org/ 10.1080/14783363.2018.1490641

Taylor, T. P. and Ahmed-Kristensen, S. 2018. Global product development projects: measuring performance and monitoring the risks. Prod. Plan. Control, 29(15), 1290-1302. https://doi.org/10.1080/09537287.2018.1520315

Tolonen, A., Shahmarichatghieh, M., Harkonen, J. and Haapasalo, H. 2015. Product portfolio management - targets and key performance indicators for product portfolio renewal over life cycle. Int. J. Prod. Econ., 170(B), 468477. https://doi.org/10.1016/j.ijpe.2015.05.034

Versiani, A. F. V., Oribe, C. Y. and Rezende, S. F. L. R. 2013. Organizational learning generated by formal practices in the work environment. RAM, 14(4), 15-44 (in Portuguese). https://doi.org/10.1590/S1678-69712013000400002

Werner, M. J. E., Yamada, A. P. L., Domingos, E. G. N., Leite, L. R. and Pereira, C. R. 2020. Exploring organizational resilience through key performance indicators. J. Ind. Prod. Eng., 38(1), 51-65. https://doi.org/10.1080/21681015.2020.1839582 


\title{
Võtmenäitajad: väikese ja keskmise suurusega tööstusettevõtete tänapäevased väljakutsed
}

\begin{abstract}
Rūta Banelienè
On analüüsitud peamisi väljakutseid väikese ja keskmise suurusega tööstusettevõtete (VKE-de) edukaks juhtimiseks globaliseeruvas maailmas ja välja pakutud mudel VKE-de protsesside edukaks hindamiseks ning jälgimiseks. Arendatud mudel on universaalne ning väikese ja keskmise suurusega tööstusettevõtted saaksid seda suhteliselt lihtsalt kasutada selliste andmebaaside väljatöötamiseks, nagu toode/materjal, seadmed ning tootmine. On antud soovitused võtmenäitajate mõõtmiseks ja jälgimiseks üheksas väärtusahelas: 1) sissetulev logistika, 2) tegevused/protsessid, 3) väljaminev logistika, 4) turustamine ja müük, 5) teenindus, 6) personalijuhtimine, 7) tehnoloogia arendamine, 8) hankimine ja 9) jätkusuutlikkus. Kolm esimest väärtusahelat on väikese ja keskmise suurusega tööstusettevõtete peamised võtmenäitajad. Turunduse, müügi ja teeninduse väärtusahelate eesmärk on mõõta ettevõtte edukust müügi kaudu. Hanke võtmenäitajad peaksid keskenduma varude mõõtmisele ja jälgimisele, tagades sujuvuse ettevõtte kõigis tegevustes. Erilist tähelepanu tuleks siiski pöörata personalijuhtimisele, uuendustele ja jätkusuutlikkusele, seadistades ning jälgides võtmenäitajaid kogu aeg: nii olevikus, minevikus kui ka tulevikus.
\end{abstract}

